\title{
Educational intervention to sensitize future retirees and work colleagues about retirement from work
}

\author{
Marie Angels Aguilera-Velasco, ${ }^{1,}$, Joseph Jesus Perez-Solis ${ }^{2}$, White Elizabeth Pozos-Radillo ${ }^{1}$ \\ ${ }^{1}$ Deparment of Health Public, University of Guadalajara, Guadalajara, México \\ ${ }^{2}$ Faculty of Mechanical Engineering, University Technology of Guadalajara, Guadalajara, México
}

\section{Email address:}

aaguileracd@hotmail.com (M. A. Aguilera-Velasco), jjesusperezs@hotmail.com (J. J. Perez-Solis), litaemx@yahoo.com.mx (W. E. Pozos-Radillo)

\section{To cite this article:}

Marie Angels Aguilera-Velasco, Joseph Jesus Perez-Solis, White Elizabeth Pozos-Radillo. Educational Intervention to Sensitize Future Retirees and Work Colleagues about Retirement from Work. Social Sciences. Vol. 3, No. 6, 2014, pp. 208-216. doi: 10.11648/j.ss.20140306.14

\begin{abstract}
A two-phase comprehensive evaluation study for the purpose of evaluating lessons learned by and expectations of future retirees and their work colleagues by means of an educational sensitization strategy towards an understanding of retirement, by Aguilera et al., (2013). 20 employees (11 pre-retirees and nine colleagues) from a Mexican hospital participated in 2013. Date was gathered with the SQA-E form. The analysis implied an initial and final naturalist criterion evaluation. None, limited, clear and practical previous knowledge was found as well as personal, learning, political-economical and procedural interests. After the conference, theoretical, practical, and practical-theoretical knowledge was obtained and political-economical, economical-political, personal, preventive, contextual, physical health and no expectations were created. Understanding and empathy by work colleagues were achieved as well as the need to become prepared, plan and have political-economic awareness in all participants. Sensitizing the general public to understand retirement is recommended.
\end{abstract}

Keywords: Preparation, Sensitization, Pre-Retirement, Work Colleagues

\section{Introduction}

The period prior to retirement is a time of crisis for one-third of employees; their anxiety levels rise, they experience difficulties in adapting to their new role and have problems in transitioning to the end of their work [1-6]. Pre-retirees fear retirement because they will have lower income and almost no possibility of finding a paying job as retirees due to the high unemployment rate. This means that they will no longer be able to maintain the life style they had before they stopped working [7]. Unfavorable attitudes towards retirement by pre-retirees have been statistically meaningfully related as well as the need for them to go through prior reparation at brief course or therapy [7].

Without preparation, it will be hard for employees to adapt to retirement; they will experience physical health and psychosocial problems (anxiety, depression and solitude among others), a lack of satisfactions and identity, social disintegration and a negative attitude towards their new situation [8].

It is urgent and vitally important to prepare those approaching retirement [9-11] and to involve their relatives in the educational activities [6]. Evidence exists that interventions to prepare employees for retirement by applying cognitive-behavioral strategies facilitate a greater satisfaction of these people with their retirement, free of anxiety and/or depression, and more enabled to live with their family and make intelligent use of their free time [12].

On the other hand, some people approaching retirement resist attending preparation courses because they imagine the free time they will dispose of as an entitlement in which nobody is authorized to intervene. In this case, perhaps a more effective strategy would be to only give some group talks with general information about the retirement stage and offer those with an unfavorable attitude brief psychological assistance enabling them to reduce the fear and anxiety with which they face this new existential stage [7].

Educational sensitization can help avoid resistance to pre-retirement courses. It is a known fact that sensitization fosters individual and collective reflection and critical awareness of the problems of retirement as well as interest in improving certain facets of life dealing with retirement and creating feelings about the need to prepare [13].

A sensitizing intervention needs the existence of a 
communication strategy as well as an evaluation of the initial and final level of acquired knowledge [13]. Furthermore, sensitization allows one to perceive the origin of the problem and favors understanding the causes [14]. Sensitization is a key factor that makes later educational actions possible [15].

Educational sensitization, by means of short intervention programs such as interactive conferences, has results comparable to longer programs because it facilitates abandoning myths and false beliefs related to the causes of the problem [16].

Participation by relatives in socio-educational sensitization actions to prepare for retirement will not suffice. Society in general must be involved in becoming aware and understanding retirement.

The ideal scenario would be for the State to take the initiative through its major educational and health institutions. Nevertheless, our Latin American societies attach little value to retirees and they are considered a financial burden in the Social Security Systems. Proof of this are the constant changes to retirement systems, where the retirement age and the required number of years worked have crept upward. In addition, scarce coverage and low pension amounts still prevail [17].

Employees approaching retirement still spend most of their time at work; any actions carried out by their colleagues to facilitate taking leave of work will have a great impact on their life and on controlling anxiety. For instance, other authors [18] discovered that if a boss affectively involves a pre-retiree close to retiring in his or her work, it will increase his or her level of anxiety. The help needed from employers is preparation for retirement and to create the conditions needed for taking leave from the workplace.

Colleagues play an important role in the process of taking leave from the workplace [19]. Work colleagues influence participants intentions to retire, whether an early or usual retirement. This influence is seen in their attitudes, behavior and opinions regarding retirement. Older colleagues validate their opinions about retiring from work with the network of work colleagues [20].
Retirement is a social phenomenon with implications for the social sphere and impacts the life of communities, both favorably and unfavorably. This is why it has been considered important to sensitize work colleagues to understand the problems faced by future retirees, with the same communication and evaluation strategies applied to retirees, pre-retirees and their relatives [13].

The general objective of this study was to evaluate lessons learned by and expectations of future retirees and their colleagues before and after implementing an educational sensitization strategy towards understanding retirement.

\section{Methodology}

\subsection{Type and Design of Study}

A two-phase comprehensive evaluation study was made. The comprehensive evaluation study consisted of determining and representing quality by means of participants' subjective knowledge, using verbal description and indirect experience of merits and deficiencies. It is a holistic episodic evaluation [21]. The space-time demarcation was a Regional General Hospital in Guadalajara, Jalisco, Mexico attending the population enrolled in the Social Security System, during the month of October, 2013.

\subsection{Participants}

Participants were selected by theoretic non-probability convenience sampling [22]. Out of a total of more than 30 hospital employees who attended an open invitation to the conference, only those cases matching the inclusion criteria were selected intentionally. The criteria in the case of pre-retirees were to have a definitive employment agreement and less than five years for their retirement date. In the case of work colleagues, the criteria were to have more than six years until their retirement date and to work with a colleague approaching retirement. 20 employees were selected. See tables 1 and 2 .

Table 1. Description of future retirees from a Hospital in México, 2013

\begin{tabular}{|c|c|c|c|c|c|}
\hline $\mathbf{N}^{\circ}$ & Age & Time to retire & Position & Sex & Illnesses \\
\hline 1 & 54 & Nothing & Medical director & Male & None \\
\hline 2 & 62 & 1 month & Nurse's assistant & Female & Hypertension \\
\hline 3 & 51 & 1 year & General nurse & Female & Hypertension \\
\hline 4 & 49 & 1 year & General nurse & Female & None \\
\hline 5 & 51 & 1.5 year & Social worker & Female & None \\
\hline 6 & 46 & 1.5 year & Nurse & Female & None \\
\hline 7 & 53 & 2.5 years & Psychologist & Female & None \\
\hline 8 & 47 & 2.5 years & Nurse in charge & Female & None \\
\hline 9 & 44 & 3 years & General nurse & Female & Hypothyroidism \\
\hline 10 & 53 & 4 years & Family doctor & Female & None \\
\hline 11 & 53 & 4 years & Family doctor & Male & None \\
\hline
\end{tabular}


Table 2. Description of work colleagues from a Hospital in México, 2013

\begin{tabular}{llllll}
\hline $\mathbf{N}^{\circ}$ & Age & Time to retire & Position & Sex & Illnesses \\
\hline 1 & 43 & 7 years & Nurse in charge & Female & Stress \\
2 & 45 & 7 year & Nurse in charge & Female & Asthma and osteoporosis \\
3 & 40 & 8 year & Social worker & Female & Overweight \\
4 & 45 & 8 year & Family doctor & Male & Insomnia and fatigue \\
5 & 48 & 10 years & Social worker & Female & None \\
6 & 45 & 12 years & General nurse & Female & None \\
7 & 39 & 14 years & Family doctor & Female & Exogenous overweight \\
8 & 41 & 16 years & Family doctor & Male & None \\
9 & 54 & 20 years & Family doctor & Female & Occasional migraine \\
\hline
\end{tabular}

\subsection{Data Collection Techniques}

Two data-gathering strategies were used: a communication strategy [14] and a self-evaluation meta-cognitive form; both are the fruit of a preliminary investigation [13].

The communication strategy consisted of an interactive conference titled "Understanding my Retirement" and included facts, information and research. It tackled topics such as different and polemic definitions of retirement, explanation of intervening factors, effects on health, political-economic situation in Mexico and Spanish America, contributions by science (scientific theories explaining work retirement and empirical studies) and the results of local investigations. It ended with practical suggestions for the people involved [13]. The conference lasted two hours and progressed in accordance with the participants' interest.

The mega-cognitive SQA-E form was used before and after the conference for participants to evaluate their own knowledge and expectations. The format was designed as a chart divided into four columns; what I know, what I want to know, what I learned, and my new expectations. People filled in the first two columns before the conference started and answered the last two columns after the conference had ended [13].

\subsection{Analysis of the Data}

The data analysis was qualitative by means of a comprehensive evaluation. Comprehensiveness is above all the virtue of being guided and being aware of praxis. This kind of comprehensive evaluation recognizes that the situations being explored are true experiences, incarnate and lived. Comprehensive evaluation implies attending to human practices of teaching or social service, understanding them as contextual experiences; that is, relations of mutual concern or attention. The analysis focused on detecting the differences of being close to retirement and being a colleague, finding their merits and value [21].

The participants' knowledge and interest in the topic of retirement were evaluated prior to the conference. Their acquired knowledge and new expectations were analyzed after the conference. We started with the participants' self-evaluation, considering that theoretical models aimed at judging merit or value enable an understanding of the phenomena [23]. The evaluation model focused on the needs of the people participating was used [21]. An evaluation process included gathering demands, interests and needs. There was an initial diagnosis (prior to the conference) and a summative final diagnosis (at the end of the conference). It was partial due to its scope and concentrated only on participants' knowledge and expectations [24].

\subsection{Ethical Considerations}

The investigation was carried out subject to the Regulations of the General Health Law on Health Research Matters in México [25], Title Two, Chapter 1, Articles 16 through 19 and 23 , given it is deemed a risk-free investigation. Participants were aware of the objectives of the study and gave their informed consent orally. The group of participants was protected as provided by the Declaration of Helsinki [26] and their identities were kept secret. The University Center that the researchers belong to, reviewed the study and approved it at the proper time.

\section{Findings}

\subsection{Prior Knowledge}

Four kinds of knowledge were found in participants prior to the conference; none, limited, clear and practical. Said previous knowledge mentioned by the participants can be seen on table 3.

Prior to the conference, it was called to our attention that two future retirees (cases 6 and 10) said they knew nothing about retirement but still reported that they were aware of the exact time left until their retirement (between 1 and 4 years respectively).

On the other hand, we found some employees approaching retirement with limited knowledge. Three subtypes of limited knowledge were identified in pre-retirement employees. The first were those whose knowledge was limited to oral information passing on the experiences of retired colleagues. This kind of subdivision allowed us to realize that there was a harmonious relation between those nearing retirement and retirees. 
Table 3. Prior knowledge of future retirees and work colleagues from a Hospital in México, 2013

\begin{tabular}{|c|c|c|c|c|}
\hline $\mathbf{N}^{\circ}$ & Future retirees: What I know & $\begin{array}{l}\text { Type of prior } \\
\text { knowledge }\end{array}$ & $\mathbf{N}^{\circ}$ & Work colleagues: What I know \\
\hline $\begin{array}{l}6 \\
10\end{array}$ & $\begin{array}{l}\text { Nothing. } \\
\text { Nothing. }\end{array}$ & Null & & \\
\hline 3 & $\begin{array}{l}\text { Only oral information from retired colleagues about } \\
\text { bureaucratic procedures. } \\
\text { Very little. They don't give us any information on this } \\
\text { topic. I don't know who or where to turn to. }\end{array}$ & & 2 & $\begin{array}{l}\text { There are more retirees than productive people. Few take } \\
\text { advantage of their retirement They die when they begin } \\
\text { retirement. }\end{array}$ \\
\hline 4 & $\begin{array}{l}\text { Retirement is the time a person has completed at work or } \\
\text { at an age to reach a period of rest. }\end{array}$ & Limited & 4 & $\begin{array}{l}\text { It is a stage when you have fewer reflexes and can no longer } \\
\text { work. }\end{array}$ \\
\hline $\begin{array}{l}5 \\
11\end{array}$ & $\begin{array}{l}\text { It is a benefit after completing years at work. } \\
\text { It's a time when I'll stop working because of my age. }\end{array}$ & & 8 & It can be due to seniority or illness. \\
\hline 7 & $\begin{array}{l}\text { Retirement age for men and women is } 27 \text { or } 28 \text { years. We } \\
\text { can begin procedures when the pay card shows the years. } \\
\text { We have to go to meetings where they will tell us the } \\
\text { papers we need to begin the process. There are activities } \\
\text { for retirees. }\end{array}$ & & 3 & $\begin{array}{l}\text { Nothing specific, just that I'll retire with my savings after } \\
27 \text { years of work plus my base salary. } \\
\text { Retirement is your right after working for years ( } 27 \text { years } \\
\text { working).It is a new stage of life that you should prepare for } \\
\text { (life project). }\end{array}$ \\
\hline 8 & $\begin{array}{l}\text { We retire after } 27 \text { years of service. When you have one } \\
\text { year to retire, try not to miss a day. I should check that my } \\
\text { information is correct before retiring, and that my cards } \\
\text { are in order. }\end{array}$ & Clear & 7 & $\begin{array}{l}\text { Nothing; after working for } 27 \text { years you retire. } \\
\text { When you retire after } 27 \text { years of work, your workdays are } \\
\text { gone. You have the freedom of not belonging to an } \\
\text { institution, with more free time. Work stress is reduced. I'll } \\
\text { have more time to devote to cultural, educational and sports } \\
\text { activities and to my family and to travel. }\end{array}$ \\
\hline 9 & $\begin{array}{l}\text { It is a time to do what we put off for later; we are going to } \\
\text { get our final payment and a pension month after month. } \\
\text { There are places where you can participate in activities. }\end{array}$ & & 9 & $\begin{array}{l}\text { Retirement comes after working for } 27 \text { years or after you } \\
\text { become } 60 \text { years old. }\end{array}$ \\
\hline 2 & $\begin{array}{l}\text { I have to file my last retirement fund statement and they're } \\
\text { going to pay me each month. }\end{array}$ & Practical & 5 & $\begin{array}{l}\text { First we have to prepare the right documents. I have to go to } \\
\text { a pre-retirement course, hang on to my pay stubs for the last } \\
\text { five years to date, file an application with the retirement } \\
\text { fund to get our money and we don't have to waste money on } \\
\text { housing. }\end{array}$ \\
\hline
\end{tabular}

Secondly, knowledge was limited to complaining about the lack of information. Thirdly, there was a limited idea of retirement as the sum of one's age and years worked, which would give them access to a time to relax. We observed a passive attitude in the first two subtypes of people nearing retirement; that is, they expected someone else (a retiree or the person in charge) to give them knowledge about a stage of their life that they were not yet familiar with but that they could plan for.

The third subtype of pre-retirees did not show any dependency but they did show conformity with the little information they had about retirement.

Further to the limited knowledge of work colleagues, cases 2 and 4 called our attention; their reported prior knowledge had to do with myths about retirement.

In the area of clear prior knowledge, we found greater clarity among employees who still had between seven and twenty years to go before retiring, than among those employees who had less than four years. This reality caused concern to the investigators.

Only one case of practical prior knowledge was found in a pre-retiree and another case in a work colleague. In both cases practicality referred to a monthly pension after retirement. We should underscore that the answer given by the work colleague was more extensive and had more details about the process.

\subsection{Prior Interests}

Four kinds of interests were found in the participants before the conference: procedural, political-economical, learning and personal. The participants' interests prior to the conference can be seen in table 4 .

Employees nearing retirement had greater expectations about receiving procedural information at the conference; they mentioned most about becoming familiar with the documents and the place where they would carry out the procedure, the amount they would be paid upon retiring, their rights as retirees and the activities they could perform once retired. This finding is congruent with the little prior knowledge they had about retirement before the conference.

On the other hand, other employees nearing retirement and other work colleagues in the same number of cases were interested in learning about the political-economic questions of retirement. Their main concern was knowing whether the labor law amendments would affect their retirement pay or would change the conditions for retiring.

Only two people nearing retirement (cases 2 and 11) were found who were interested in learning about retirement issues. We should mention that the person of case 2, who already had practical knowledge about the amount and manner in which she would receive her retirement pay and had only a month left before retiring, showed interest in learning as much as possible about this new stage of her life. Case 11, a physician who proved to have knowledge about himself and whose prior 
knowledge was limited (that's when I'll stop working because of my age) took advantage of the opportunity to expand his

knowledge about retirement.

Table 4. Prior interests of future retirees and work colleagues from a Hospital in México, 2013

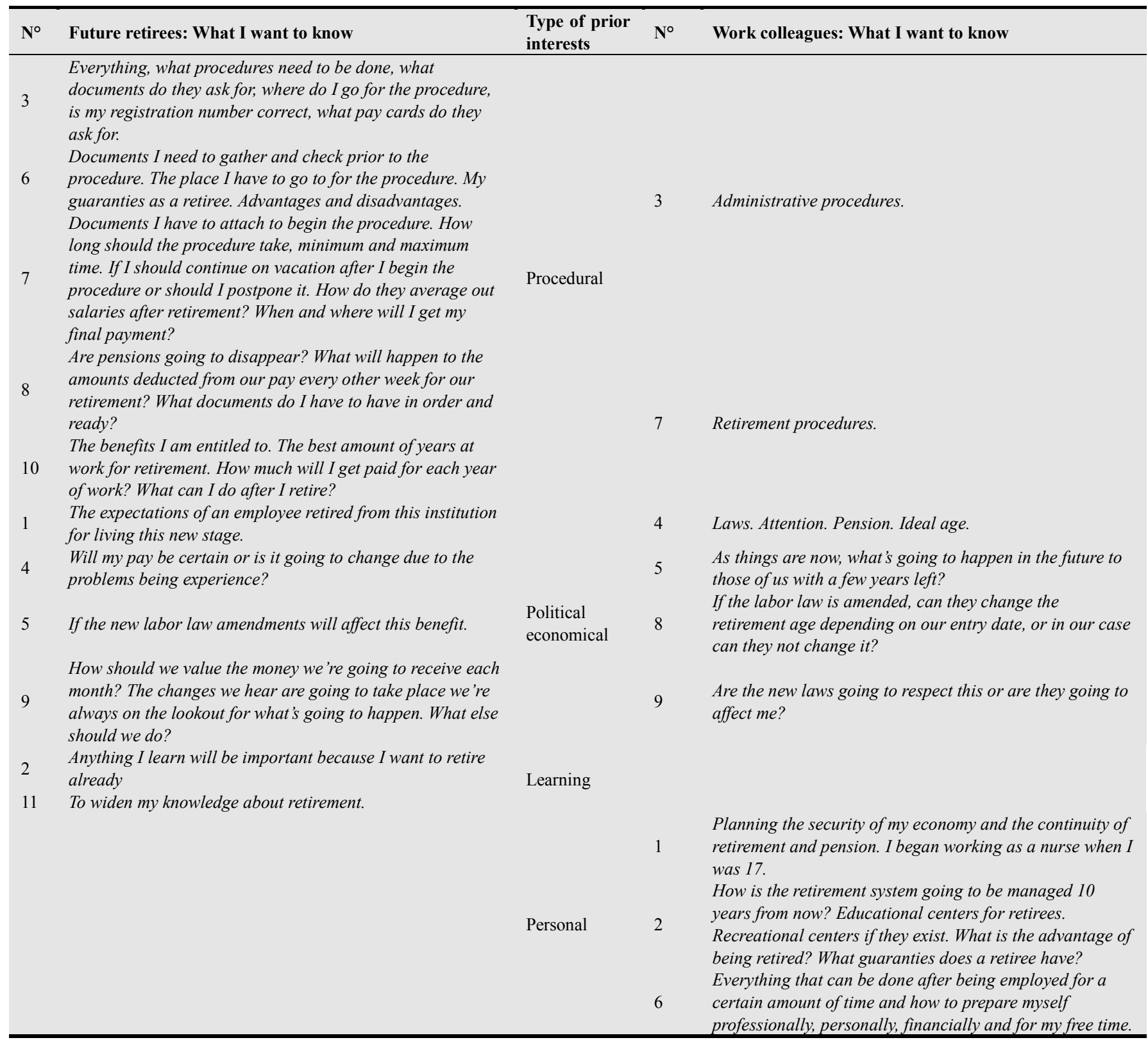

Interest in learning personal kinds of issues was present in three work colleagues. Investigators found it stimulating that some of the work colleagues they studied wanted to plan their retirement professionally, financially as well as the use of their free time, and they also wanted to maintain and widen their social network at centers for retirees. Nevertheless, upon comparing their personal interests with those of people nearing retirement, another urgent focus of attention was found; employees about to stop working in a very short time and face retirement did not show any personal interests with a clear and encouraging vision.

\subsection{Acquired Knowledge}

We found three kinds of knowledge in participants after the conference: theoretical, practical and theoretical-practical. The acquired knowledge can be seen in table 5 .

A balance was struck among the three kinds of acquired knowledge. For instance, in the area of theoretical knowledge, pre-retirees as well as their colleagues said that had learned about the stages of retirement, the theories that explain them, and the retiree syndrome. They broadened their concept of retirement, learned they needed to have a life project, the support of a social network and to perform altruistic activities. Curiously enough, the three cases of pre-retirees related acquired knowledge with feelings and values. 
Table 5. Lessons learned of future retirees and work colleagues from a Hospital in México, 2013

\begin{tabular}{|c|c|c|c|c|}
\hline $\mathbf{N}^{\circ}$ & Future retirees: What I learned & $\begin{array}{l}\text { Type of lessons } \\
\text { learned }\end{array}$ & $\mathbf{N}^{\circ}$ & Work colleagues: What I learned \\
\hline 1 & $\begin{array}{l}\text { Stages and the feelings held by people who are going to } \\
\text { retire. }\end{array}$ & \multirow[t]{4}{*}{ Theoretical } & 3 & $\begin{array}{l}\text { Retirement is not just a bureaucratic procedure; it is a } \\
\text { moment or a number of stages requiring changes of life } \\
\text { style to adapt healthfully to the time when you are no } \\
\text { longer at work or at the institution. Retirees need the } \\
\text { support of company and love to facilitate this process of } \\
\text { change. }\end{array}$ \\
\hline 7 & Theories about retirement and values. & & 4 & A lot of good things. \\
\hline 10 & $\begin{array}{l}\text { What retirement means. What should we do to have a life } \\
\text { project for retirement? }\end{array}$ & & 5 & $\begin{array}{l}\text { Retirement is a stage of my life but for preparation, } \\
\text { personal care, pension, independence and family, besides }\end{array}$ \\
\hline 11 & There are seven stages and there is a retiree syndrome. & & & having altruistic activities. \\
\hline 2 & $\begin{array}{l}\text { I should prepare all aspects to be able to enjoy retirement } \\
\text { and not be a burden for my family and society. }\end{array}$ & \multirow{5}{*}{ Practical } & 1 & $\begin{array}{l}\text { Plan a family project. Healthcare. Financial stability. } \\
\text { Continuity in enjoying life and wellbeing in a family } \\
\text { setting. }\end{array}$ \\
\hline 3 & $\begin{array}{l}\text { We have to plan for the future, take care of ourselves as of } \\
\text { now. }\end{array}$ & & 2 & $\begin{array}{l}\text { It is the end of the work cycle. We have to plan, accept it } \\
\text { enthusiastically and joyfully so that its effects don t affect } \\
\text { us and harm our everyday life or our family, and forge } \\
\text { social networks. Be productive still in my community. } \\
\text { Mexico has to overcome the effects of retirement and give } \\
\text { support to companies to give courses to pre-retirees. }\end{array}$ \\
\hline 4 & $\begin{array}{l}\text { I have to plan my retirement, not make farfetched plans. } \\
\text { Accept it joyfully, try to lead a healthy life. }\end{array}$ & & 8 & $\begin{array}{l}\text { The final stage of a } 27 \text { to } 30 \text {-year work period We should } \\
\text { prepare ourselves physically, emotionally, and be mindful } \\
\text { of our physical health so we may enjoy this period. The } \\
\text { country's socioeconomic situation may change and we } \\
\text { need to be prepared professionally and economically for } \\
\text { pre- and post retirement. The expectation is for life to } \\
\text { continue with other activities. }\end{array}$ \\
\hline 5 & We have to be prepared in our three spheres for & & & \\
\hline 6 & $\begin{array}{l}\text { retirement. } \\
\text { Plan our time and maintain monetary income. Achieve } \\
\text { our personal expectations with our family, children, } \\
\text { grandchildren and spouse, parents and other close } \\
\text { relatives, with health, happiness and an accomplished } \\
\text { goal. Be thankful for time. }\end{array}$ & & 9 & $\begin{array}{l}\text { It doesn t matter if the law favors me or not, or if I retire } \\
\text { sooner or later, just my mental attitude, my physical and } \\
\text { mental wellbeing. Cultivate my family relationships and } \\
\text { with my friends and take care of my health as of now. }\end{array}$ \\
\hline 8 & $\begin{array}{l}\text { Modifications that retirement or changes could cause us. } \\
\text { It is good to plan our retirement as I'm going to do. Plan } \\
\text { my time, keep busy. A vision of retirement. }\end{array}$ & \multirow[b]{2}{*}{$\begin{array}{l}\text { Theoretical-prac } \\
\text { tical }\end{array}$} & 6 & $\begin{array}{l}\text { The importance that keeping and promoting health has. } \\
\text { Income, financial security. Social support, friends and } \\
\text { family. Planning; we should organize our retirement, make } \\
\text { plans and carry them out. }\end{array}$ \\
\hline 9 & $\begin{array}{l}\text { Planning my life after retirement. I learned the different } \\
\text { steps of retirement and we have to go through each of } \\
\text { them. A change of life is not easy but we have to adapt to } \\
\text { our new way of living. }\end{array}$ & & 7 & $\begin{array}{l}\text { It is important to plan our retirement to enjoy it } 100 \% \text { and } \\
\text { also to enjoy the present The present we have paves the } \\
\text { way to the future we will have. We have to take care of } \\
\text { ourselves and our family and interpersonal relationships; } \\
\text { we will reap what we sow. }\end{array}$ \\
\hline
\end{tabular}

As for practical acquired knowledge, they said they had clearly defined the need to plan in a realistic fashion, considering their income and time available as well as having a positive attitude (feeling happy, enthusiastic and grateful); getting ready for retirement by taking courses in all the vital areas; taking care of their health; making frequent contact with relatives; and continue to be productive, all the above to avoid becoming dependent on family and society and to get some satisfaction out of life.

The theoretical and practical lessons learned in general allowed us to observe that it was possible for pre-retirees and their colleagues to transfer theoretical knowledge to their particular life situation.

\subsection{New Expectations}

We found six different kinds of expectations after the conference: political-economic, personal political-economic, none, preventive, contextual and physical health as seen in table 6 .

In the inquiries about the topics that the conference did not cover but that had awakened new interests among participants, one pre-retiree and one work colleague were found who had become afraid of government policies and their repercussions on the retirement of those working in health institutions.

On the other hand, the conference also produced new concerns about political-economic and personal matters. Two pre-retirees and two work colleagues recognized they could not remain passive towards government retirement policies, and faced with their reality as retired people, remain active and productive. They mentioned in this regard that they could take up the fight in favor of the right to retire along with taking care of their overall health. 
Table 6. New expectations of future retirees and work colleagues from a Hospital in México, 2013

\begin{tabular}{|c|c|c|c|c|}
\hline $\mathbf{N}^{\circ}$ & Future retirees: My new expectations & $\begin{array}{l}\text { Type of new } \\
\text { expectations }\end{array}$ & $\mathbf{N}^{\circ}$ & Work colleagues: My new expectations \\
\hline 1 & Doubts and fear about future policies remain. & $\begin{array}{l}\text { Political } \\
\text { economical }\end{array}$ & 8 & $\begin{array}{l}\text { Improve my knowledge of retirement policies in general } \\
\text { and those of my institution to be prepared and influence } \\
\text { my life plans. }\end{array}$ \\
\hline 6 & $\begin{array}{l}\text { There is no valuation or courage to fight against taking } \\
\text { retirement away from future generations and to keep } \\
\text { social security that our predecessors fought for and for } \\
\text { the retirement system of our Mexican Social Security } \\
\text { Institute. Participative expectations, realistic regarding } \\
\text { health and substituting work at the hospital for work at } \\
\text { home, staying active in different activities. }\end{array}$ & $\begin{array}{l}\text { Personal } \\
\text { Political } \\
\text { economical }\end{array}$ & 2 & $\begin{array}{l}\text { As for the government and the reforms, what is my } \\
\text { retirement and where is my retirement headed for? Prepare } \\
\text { myself and continue being productive for my family. Look } \\
\text { for alternatives to increase my savings and have enough to } \\
\text { maintain myself when I'm old. }\end{array}$ \\
\hline 9 & $\begin{array}{l}\text { What's going to happen with so many changes they say } \\
\text { are coming? Enjoy my family and do everything I } \\
\text { couldn't do before because I had to go to work. }\end{array}$ & & 9 & $\begin{array}{l}\text { Just the legal issues, the new law and how it's going to } \\
\text { affect my retirement. But the important thing is my } \\
\text { physical and emotional wellbeing. }\end{array}$ \\
\hline 2 & $\begin{array}{l}\text { My expectations of life are going to be the same or } \\
\text { similar once I retire. }\end{array}$ & & & \\
\hline $\begin{array}{l}3 \\
4\end{array}$ & $\begin{array}{l}\text { None. } \\
\text { Everything's fine conoratulations }\end{array}$ & Null & 4 & Everything's fine. \\
\hline 11 & $\begin{array}{l}\text { I learned everything about retirement. My expectations } \\
\text { improved. }\end{array}$ & & & \\
\hline 5 & Become ware; prevention will be better. & & 3 & $\begin{array}{l}\text { I need to prepare to be able to reach that moment I have } \\
\text { longed for. The importance of becoming involved in the } \\
\text { change process with relatives and colleagues. }\end{array}$ \\
\hline 8 & $\begin{array}{l}\text { How I should plan my retirement, take care of my health, } \\
\text { save as much as I can and not be afraid of my retirement. }\end{array}$ & Preventive & 6 & $\begin{array}{l}\text { Project to promote and carry out self-care. Keep active. An } \\
\text { active old age. More physical, family and social ties. } \\
\text { Financial security. Altruistic activities. }\end{array}$ \\
\hline 10 & $\begin{array}{l}\text { I learned that my new expectation is to have a retirement } \\
\text { project. }\end{array}$ & & 7 & $\begin{array}{l}\text { To plan as of today a step at a time to love, to understand } \\
\text { others and with this to revive in the future. If you give love, } \\
\text { you will receive love many times over. }\end{array}$ \\
\hline \multirow[t]{2}{*}{7} & $\begin{array}{l}\text { About the Social Security bureaucratic procedures. A } \\
\text { course on pre-retirement. }\end{array}$ & Contextual & 5 & $\begin{array}{l}\text { I didn't learn what I really wanted to know about future } \\
\text { preparation at work and my expectations are entirely } \\
\text { preventive. I do not agree with the new labor law } \\
\text { amendments. }\end{array}$ \\
\hline & & Physical health & 1 & $\begin{array}{l}\text { Family and social wellbeing (good decision-making about } \\
\text { retirement systems). I fear for my physical health due to } \\
\text { the demands of my work. I take measures such as physical } \\
\text { exercise, occupational therapy so my physical and mental } \\
\text { wellbeing are not affected and I try to perform another } \\
\text { activity. I wind up actively exhausted. }\end{array}$ \\
\hline
\end{tabular}

In the case of four pre-retirees and one work colleague, the conference did not spark any new interests; they simply thought the information provided to them was alright.

As for new preventive type interests, the most noteworthy were participants nearing retirement mentioning that they had become aware of having to take care of their health, and saving and planning. Besides the above-mentioned concerns, work colleagues mentioned they needed to prepare, involve their family, remain active and carry out altruistic activities. In this regard, it can be seen that the new expectations generated by the conference were deeper and more intense in work colleagues.

New contextual expectations were seen in only one pre-retiree, and seven had similar interests before and after the conference, the difference being that the former recognized the need of a pre-retirement course.

\subsection{Meta-Cognitive Learning Process}

The extract of the meta-cognitive learning process by pre-retirees and colleagues is found in table 7.
The analysis of this process allows us to observe the evolution of each case before and after the conference, and to realize that no two cases are the same; i.e., there is heterogeneity in the results obtained from the brief intervention in each particular case. There was no case of pre-retirees or work colleagues $100 \%$ similar to any other case despite coming from the same work environment and sharing some sociodemographic and health traits.

For instance, a match was found in pre-retiree cases 6 and 10 with no prior knowledge and prior procedural expectations but these two cases did not share the lessons learned or the same kind of new expectations generated by the awareness conference.

Another example is pre-retiree cases 1, 4 and 5; they all expressed limited knowledge and shared political-economical expectations but only cases 4 and 5 shared the same lessons learned at the conference and no match was found in the three cases regarding new expectations. 
Table 7. Meta-cognitive learning process of future retirees and work colleagues from a Hospital in México, 2013

\begin{tabular}{|c|c|c|c|c|c|c|c|c|c|}
\hline \multicolumn{5}{|c|}{ Future retirees } & \multicolumn{5}{|c|}{ Work colleagues } \\
\hline $\mathbf{N}^{\circ}$ & $\mathbf{S}$ & $\mathbf{Q}$ & $\mathbf{A}$ & $\mathbf{E}$ & $\mathbf{N}^{\circ}$ & $\mathbf{S}$ & $\mathbf{Q}$ & $\mathbf{A}$ & $\mathbf{E}$ \\
\hline 1 & Limited & $\begin{array}{l}\text { Political } \\
\text { economical }\end{array}$ & Theoretical & $\begin{array}{l}\text { Political } \\
\text { economical }\end{array}$ & 1 & Clear & Personal & Practical & Physical health \\
\hline 2 & Practical & Learning & Practical & Null & 2 & Limited & Personal & Practical & $\begin{array}{l}\text { Personal } \\
\text { Political } \\
\text { economical }\end{array}$ \\
\hline 3 & Limited & Procedural & Practical & Null & 3 & Clear & Procedural & Theoretical & Preventive \\
\hline 4 & Limited & $\begin{array}{l}\text { Political } \\
\text { economical }\end{array}$ & Practical & Null & 4 & Limited & $\begin{array}{l}\text { Political } \\
\text { economical }\end{array}$ & Theoretical & Null \\
\hline 5 & Limited & $\begin{array}{l}\text { Political } \\
\text { economical }\end{array}$ & Practical & Preventive & 5 & Practical & $\begin{array}{l}\text { Political } \\
\text { economical }\end{array}$ & Theoretical & Contextual \\
\hline 6 & Null & Procedural & Practical & $\begin{array}{l}\text { Personal Political } \\
\text { economical }\end{array}$ & 6 & Clear & Personal & Theoretical-practical & Preventive \\
\hline 7 & Clear & Procedural & Theoretical & Contextual & 7 & Clear & Procedural & Theoretical-practical & Preventive \\
\hline 8 & Clear & Procedural & Theoretical-practical & Preventive & 8 & Limited & $\begin{array}{l}\text { Political } \\
\text { economical }\end{array}$ & Practical & $\begin{array}{l}\text { Political } \\
\text { economical }\end{array}$ \\
\hline 9 & Clear & $\begin{array}{l}\text { Political } \\
\text { economical }\end{array}$ & Theoretical-practical & $\begin{array}{l}\text { Personal Political } \\
\text { economical }\end{array}$ & 9 & Clear & $\begin{array}{l}\text { Political } \\
\text { economical }\end{array}$ & Practical & $\begin{array}{l}\text { Personal Political } \\
\text { economical }\end{array}$ \\
\hline 10 & Null & Procedural & Theoretical & Preventive & & & & & \\
\hline 11 & Limited & Learning & Theoretical & Null & & & & & \\
\hline
\end{tabular}

Another example: work colleagues cases 3 and 7 shared the same kinds of prior knowledge, prior expectations and new expectations generated by the conference but each had a different kind of acquired knowledge. Curiously enough, work colleagues 3 and 7 also shared being overweight. On the other hand, cases 4 and 8 , both male physicians, shared the same limited prior knowledge and prior political-economical expectations, but had completely different lessons learned and post-conference expectations.

\section{Discussion}

Future retirees and their colleagues showed (present and future) interest in the political-economic effects of retirement on their income and labor guaranties [7, 17].

The need to prepare for retirement with pre-retirement courses was found in the great majority of the participants [7]. A lack of identity in pre-retirees was also found, similar to other investigator [8] when there is a lack of preparation activities.

The urgent need to prepare those approaching retirement is confirmed [9-11] and their relatives [6] and their colleagues; it turned out to be a good idea to involve work colleagues in the sensitization process [18-20].

In accordance with other authors [13-16], we also found in this intervention the advantages of educational sensitization through a brief interactive conference, given that understanding and critical awareness of the problem was achieved a well as the desire to prepare, plan and improve retirement life.

\section{Conclusions}

The objectives of the study were met. The SQA-E form and the interactive conference were the sensitization tools that provided understanding and empathy by colleagues, the need to prepare and plan as well as awareness of the workplace political-economical procedures by all participants.

The next step in educational intervention is to invite the community at large to participate in socio-educational sensitization because preparing for retirement is a phenomenon that should involve all social spheres. We suggest that retirees and those about to retire prepare themselves through education for this new stage of their life; that investigators propose to continue to carry out interventions to prepare for retirement, characterized by systemization and theoretical rationale; education and health institutions, employers and union leaders should promote and lend support to retirement preparation activities.

\section{References}

[1] R. C. Atchley, "Retirement and leisure participations: continuity or crisis?", The Gerontologist. Vol. 11, No. 1, 1971, pp. 13-17.

[2] V. Braithwaite, and D. Gibson, "Adjustment to retirement: what we know and what we need to know", Aging and Society. Vol. 7, 1987, pp. 1-18

[3] R. Bossé, C, Aldwin, R. Levenson, and K. workman-Daniels, "How stressful is retirement? Fundings from the normative aging study", Journal of Gerontology: psychological sciences. Vol. 46, No. 1, 1991, pp. 9-14.

[4] R. Jensen-Scott, "Counseling to promote retirement adjustment", Career Development Quarterly. Vol. 41, 1993, pp. 257-267.

[5] J. Theriault, "Retirement as a psychosocial transition: Process of adaptation to change", International Journal of Aging and Human Development. Vol 38, 1994, pp. 153-170.

[6] R. Moragas, P. Rivas, R. Cristofol, N. Rodríguez, and C. Sánchez, "Estudio: Prevención dependencia. Preparación para la jubilación - dos", Barcelona: Parc Cientific, 2006. 
[7] N. Rodríguez, "Actitudes hacia la jubilación", Interdisciplinaria. Vol. 24, No. 1, 2006, pp. 5-42.

[8] G. Hernández, "Cese de la actividad profesional y preparación para la jubilación". Cuadernos de Relaciones Laborales. Vol. 27, No. 2, 2009, pp. 63-81.

[9] M. Limón, "La preparación a la jubilación: nueva ocupación del tiempo", Revista Complutense de Educación. Vol. 4, No. 1, 1993, pp. 53-67.

[10] G. Madrid, and F. Garcés, "La preparación para la jubilación: revisión de los factores psicológicos y sociales que inciden en un mejor ajuste emocional al final del desempeño laboral", Anales de Psicología. Vol. 16, No. 1, 2000, pp. 87-98.

[11] J. De las Heras, "La preparación para la jubilación: proyecto madurez vital", Congreso Nacional de Organización de Mayores. Madrid: Taurus, 2004.

[12] V. Skoknic, "Efectos de la preparación psicológica para la jubilación”, Revista Intervención Psicosocial. Vol. 7, No. 1, 1998, pp. 155-167.

[13] M. A. Aguilera, J. J. Pérez, D. D. Delgado, M. I. Contreras, M. Acosta, and B. E. Pozos, "Educational preparation of older adults and their families for retirement", Advances in Applied Sociology. Vol. 3, No. 6, 2013, pp. 237-245.

[14] EQual, "Módulo II: La sensibilización como estrategia de cambio", Andalucía: Unión Europea, 2011.

[15] R. Chicharro, and J. Maza, "Programas de educación y sensibilización”, Tiempo de Paz. Vol. 89, 2008, pp. 153-156.

[16] S. Pick, I. Leenen, M. Givaudan, and A. Prado, "Yo quiero, yo puedo... prevenir la violencia: Programa breve de sensibilización en el noviazgo", Salud Mental. Vol. 33, No. 2, 2010, pp. 153-160.
[17] R. Chande, "Trabajo y jubilación. Insuficiencia actual y cambios necesarios", Rev. DEMOS. Vol. 16, 2003, pp. 37-38.

[18] R. Chiesa, and G. Sarchielli, "Prepararse para la jubilación. El papel del apoyo social en la gestión de la ansiedad", Revista de Psicología del Trabajo y de las Organizaciones. Vol. 24, No. 3, 2008, pp. 365-388.

[19] K. Potocnik, N. Tordera, and J. Peiró, "The influence of the early retirement process on satisfaction with early retirement and psychological well-being", International Journal of Aging \& Human Development. Vol. 70, No. 3, 2010, pp. 251-273.

[20] H. R. F. Ebaugh, "Becoming an ex: The process of role exit", Chicago: University of Chicago Press, 1988.

[21] R. E. Stake, "Evaluación comprensiva y evaluación basada en estándares”, Barcelona: Graó, 2013.

[22] M. Q. Patton, "Qualitative evaluation and research methods", London: Sage, 1990.

[23] S. Castillo, and J. Cabrerizo, "Evaluación de programas de intervención socioeducativa, agentes y ámbitos", Madrid: Pearson Prentice Hall, 2004.

[24] M. A. Casanova, "Manual de evaluación educativa", Madrid: La Muralla S. A., 1999.

[25] Diario Oficial de la Federación, "Reglamento de la Ley General de Salud en Materia de Investigación para la Salud", México: Estados Unidos Mexicanos, 1983.

[26] Asociación Médica Mundial, "Declaración de Helsinki: principios éticos para las investigaciones médicas en seres humanos", Corea: Asociación Médica Mundial, 2008. 